Bangl. J. Vet. Med. (2011). 9 (2) : $133-136$

\title{
DETECTION OF AVIAN INFLUENZA VIRAL ANTIGEN IN DUCKS OF HAOR AREAS OF NETRAKONA DISTRICT USING RAPID TEST KITS
}

\author{
R. R. Sarker ${ }^{1 *}$, M. S. Rahman ${ }^{1}$, M. J. Uddin ${ }^{1}$ and M. A. H. N. A. Khan ${ }^{2}$ \\ ${ }^{1}$ Department of Medicine, ${ }^{2}$ Department of Pathology, Faculty of Veterinary Science, Bangladesh Agricultural \\ University, Mymensingh-2202, Bangladesh. ${ }^{*}$ Corresponding author’s e-mail: romasarker.bau@gmail.com
}

\begin{abstract}
The study was carried out to detect the presence of Avian Influenza (AI) viral antigen using rapid antigen detection kit from free ranged ducks in haor areas of Bangladesh. The cloacal swabs were collected randomly from 20 duck farms of two Upazilas of Netrakona district and a total of 65 field samples were tested in this study. The overall proportion of avian influenza $\mathrm{H} 5$ antigen positive reactivity was $6.2 \%$ in Netrakona district. The proportion of avian influenza $\mathrm{H} 5$ antigen positive reactivity was 6.7\% in Netrakona Sadar. Beside in Atpara Upazila, the proportion of avian influenza H5 antigen positive reactivity was $5.7 \%$. In this study, there was no significant ( $>>0.05)$ relationship between the presence of AIV in domestic ducks in two Upazilas. This is the first report that successfully detect avian influenza virus antigen in ducks of Bangladesh using rapid test kits. The duck in the haor area could act as a source of AI viruses towards infecting domestic chickens and other free living birds of Bangladesh.
\end{abstract}

Key words: Avian Influenza virus, rapid antigen detection kit, ducks, Bangladesh

\section{INTRODUCTION}

Wild ducks are the natural reservoir of avian influenza viruses (AIVs), from which the virus can spread to other species including humans, poultry and swine and thus play an important role in the ecology and transmission of these viruses (El Zowalaty et al., 2011; Munster et al., 2009; Webster et al., 1992;). Avian Influenza virus is a RNA virus having the negative-sense segmented ssRNA which belongs to the Orthomyxoviridae family. The virus is genetically diverse and typed according to the combination of two surface proteins: the haemagglutinin (HA) and the neuraminidase (NA). Serologically, 16 subtypes of HA (H1-H16) and 9 subtypes of NA (Nl-N9) have been identified (Fouchier et a1., 2005). Nearly all possible combinations of the $16 \mathrm{HA}$ and 9 NA antigenic subtypes have been found in ducks (Gaidet et al., 2012; Munster et al., 2009). The proportion of mallards infected by AIV varied in a seasonally consistent way, being lower (less than 10\%) during the spring and summer and higher (10-25\%) during autumn migration and early winter (Wallensten et al., 2007). A similar annual temporal pattern occurs in North America (Krauss et al., 2004), and seems to be a general feature of AIV ecology (Olsen et al., 2006). Due to change in biology avian influenza virus increased in virulence in wild flocks and developed into a highly pathogenic strain in domestic ducks (Hulse-Post et al., 2005; FAO, 2010). There are report of death of many domestic and exotic waterfowl in Hong Kong nature parks in late 2002; the birds had systemic viremia and showed signs of neurologic disease (Sturm-Ramirez et al., 2004; Ellis et al., 2004). LPAI (Low pathogenic avian influenza) strains produce pathological pneumonia-like lesions in the lungs of infected ducks (Cooley et al., 1989). It has been reported that HPAI (Highly pathogenic avian influenza) viruses is associated with clinical signs and mortality of ducks in Bangladesh (Nooruzzaman et al., 2012). Since the first outbreak of HPAI (H5N1) in commercial chicken encountered on $5^{\text {th }}$ February, 2007 at Sharishabari Upozilla, Jamalpur district (OIE, 2008), there are limited reports about the occurance of pathogenic AIV in ducks in Bangladesh. In Bangladesh conventional methods such as clinical signs and post mortem lesions are being practiced for the diagnosis of avian influenza. Reverse Transcripatse Polymerase Chain Reaction (RT-PCR) infrequently used by Bangladesh Livestock Research Institute (BLRI) and the Department of Pathology, Bangladesh Agricultural University to identify AI viral RNA from field outbreaks (Bari et al., 2010; Majumder et al., 2011). There are kits available to the service provider of Directorate of Livestock services (DLS) in order to identify field outbreaks of AI in chickens but little work has been done in ducks about the occurance of AI. However, rapid and accurate detection of AI viral antigens in ducks need to adopt towards identifying avian influenza viruses at their earlier onset. 


\section{R. R. Sarker and others}

In ducks, the ability to detect influenza Type A viruses is dependent upon the avaiability of prompt and accurate diagnostic method (Munster et al., 2009). Although various techniques are available for the detection and subtyping of avian influenza viruses, it is believed that use of rapid test kits is one of the most sensitive techniques and the test kit can be used for the detection of influenza viral antigen in ducks (Rahman et al., 2012). RapiGEN AIV $\mathrm{H}_{5}$ Ag test kit (AIV $\mathrm{H}_{5}$ Ag test kit, RapiGEN incorporation, South Korea) is a solid phase chromatographic immunoassay with monoclonal antibody to the highly conserved nucleocapsid protein of AIV Type A influenza virus for the specific detection of antigen in cloaca, trachea and ground feces. The aim of this study was to identify Type A Avian influenza virus (H5 antigen) using rapid test kit and to know the occurance of AIVs in the ducks of haor areas of netrakona district.

\section{MATERIALS AND METHODS}

\section{Collection of samples}

A total of 65 cloacal swab samples from 20 duck farms of Netrakona sadar and Atpara Upazilas, Netrakona, Bangladesh were collected during the period from June to December 2011. Among the 65 cloacal swab samples 30 were collected from Netrakona sadar and 35 from Atpara Upazila. Samples were collected randomly from each duck farm without distinction between healthy and sick ducks (Fig. 1).

\section{Test procedure of AIV Rapid Ag kit}

The test was performed with the help of AIV $\mathrm{H}_{5} \mathrm{Ag}$ test kit as per the instruction of the manufacturer (RapiGEN Incoorporation, South Korea). After collection of samples, the stick (cloacal swab) was inserted into the buffer bottle and the top portion was securely dissolved onto the base. Then the stick was snapped to make the length suitable to bottle. The cap of bottle was screwed and agitated for 10 seconds by shaking vigorously to ensure good sample extraction. The entire reagent was turned into room temperature before running the assay. The test device was removed from its sealed pouch by tearing the notch. The top of the bottles were snapped. 4-5 drops of sample were dispensed into the sample well by squeezing the bottle. Results of the test were obtained within 3-5 minutes but waited for 20-30 minutes. The result was recorded by naked eye detection of single band for negative control, double band for AIV (Fig. 2).

\section{Statistical analysis}

$\mathrm{Chi}^{2}$ test with continuity correction was done to find out the significant variation in the presence of avian influenza virus in two Upazilas by using SPSS 17.0.

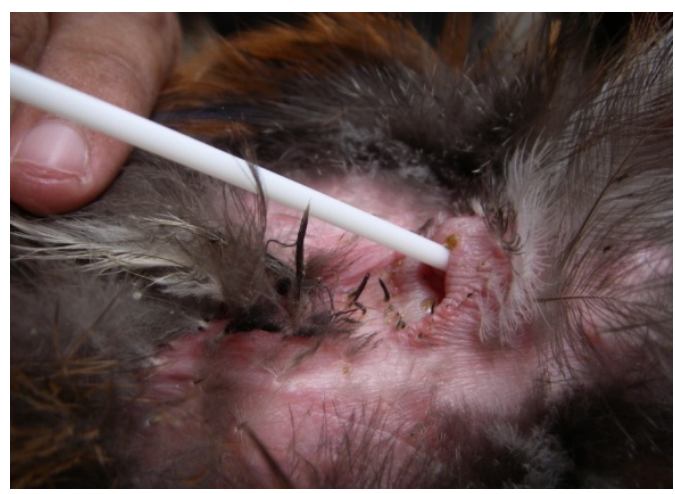

Fig. 1. Collection of cloacal swab from duck

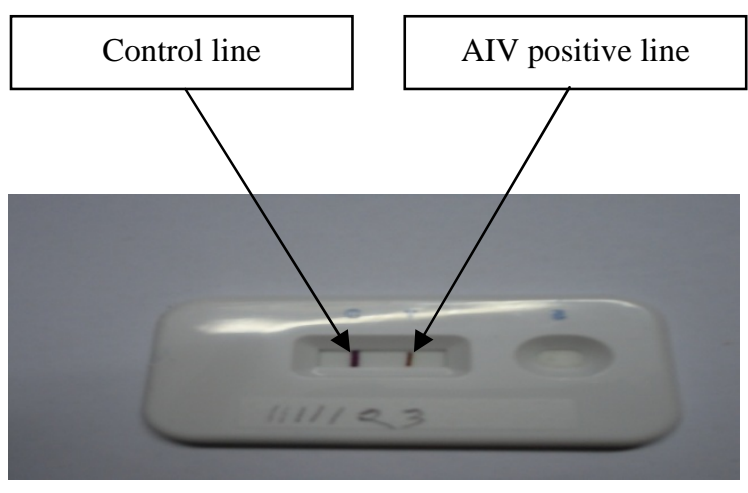

Fig. 2. AIV H5 Ag test kit showing positive result 


\section{RESULTS AND DISCUSSION}

The research work was designated to determine the presence of Type A Avian Influenza Virus (AIV) in domestic ducks of Netrakona district, Bangladesh. A total of 65 Cloacal swab samples were tested for the presence of avian influenza viral antigen. Results of the test were recorded by observing the single band for negative control, double band for AIV positive cases within 3-5 minutes. Out of 65 samples, 4 samples appeared positive for AIV and overall proportion for positive cases was 6.2\%. Out of 30 samples in Netrakona sadar, 2 were found positive, therefore, the propotion of avian influenza $\mathrm{H} 5$ antigen reactivity was $6.7 \%$. On the other hand in Atpara Upazila, out of 35 samples tested, 2 were found positive with a propotion of avian influenza H5 antigen reactivity was $5.7 \%$. In this study, there was no significant ( $p>0.05)$ relationship between the presence of AIV in domestic ducks in two Upazilas (Table 1).

Table 1. Avian influenza virus detected from domestic ducks of two upazilas of Netrakona Districts

\begin{tabular}{|lcccc|}
\hline Upazilas & $\begin{array}{c}\text { No. of sample } \\
\text { tested }\end{array}$ & $\begin{array}{c}\text { No. of positive } \\
\text { reactors }\end{array}$ & $\begin{array}{l}\text { Percentage (\%) of } \\
\text { positive reactors }\end{array}$ & $\begin{array}{c}\text { Level of } \\
\text { significance }\end{array}$ \\
\hline $\begin{array}{l}\text { Netrakona } \\
\text { sadar } \\
\text { Atpara }\end{array}$ & 30 & 2 & $(6.7 \%)$ & NS \\
\hline Total & 35 & 2 & $(5.7 \%)$ & NS \\
\hline
\end{tabular}

NS = Not significance $(\mathrm{p}<1.0)$

Very little information is available regarding the occurrence of AIV in domestic ducks in Bangladesh (Rahman et al., 2012; Nooruzzaman et al., 2012). In a study Rahman et al. (2012) used rapid test kit to detect AI viral antigen in ducks but failed to detect any antigenic reactivity. This study used rapid antigen test kit and successfully detected $\mathrm{H} 5$ antigen in the cloacal swabs (6.2\% cases) in haor ducks during late autumn and early winter and indicated infectivity of ducks with $\mathrm{H} 5$ avian influenza viruses. This annual temporal pattern is similar that occurs in Northern Europe (Wallensten et al., 2007) and North America (Krauss et al., 2004). This may be due to spread of the virus among the ducks at the time of scavenging and contact with migratory water fowl in the haor during these seasons.

AIV firstly detected in Bangladesh in the year 2007 and since then the disease has got much importance. Now a day the disease is assuming to be endemic in the domestic chicken and ducks in Bangladesh. Most of the ducks are reared in the haor areas of Bangladesh. They are free living; could have contact with wild migratory birds. The way by which the domestic chickens infected with AIV was not known in Bangladesh. However, ducks in the haor area could act as a source of AI viruses towards infecting domestic chickens and other free living birds. This is the first report that successfully detect avian influenza virus antigen in ducks of Bangladesh using rapid test kits.

Virulent serotype specially the $\mathrm{H}_{7}$ and $\mathrm{H}_{5}$ AIV may cause morbidity and mortality in ducks. In this study we detected $\mathrm{H}_{5}$ antigen of AIV by using AIV $\mathrm{H}_{5}$ rapid Ag test kit. The test is very easy, rapid, less laborious and inexpensive and can be considered as a rapid screening method for the detection of AIV in Bangladesh. Further studies are needed targetting the determination of sensitivity and specificity of the kit for wide use in field condition, serotype determination and molecular detection of the field isolates. Test kit developed using monoclonal antibodies against H1, H5, H7 and H9 antigens of AI viruses and detected serotypes accordingly from the field outbreaks/ suspected cases/ carrier cases would be highly valuable.

\section{ACKNOWLEDGEMENTS}

The authors are grateful to RapiGEN Incorporation, South Korea for supplying the kits to the $2^{\text {nd }}$ author in Bangladesh as free samples. 


\section{R. R. Sarker and others}

\section{REFERENCES}

1. Bari T, Khan MAHNA, Islam MT, Happy SA, Pervin M and Chowdhury EH (2010). Pathological and molecular detection of Avian Influenza in layer chickens from a field outbreak in Bangladesh. Bangladesh Veterinary Journal (Paper in press).

2. Cooley AJ, Van CH, Philpott MS, Easterday BC and Hinshaw VS (1989). Pathological lesions in the lungs of ducks infected with influenza A viruses. Veterinary Pathology 26 : 1-5.

3. El Zowalaty ME, Abin M, Chander Y, Redig PT and Goyal SM (2011). Improved method for the isolation and sub-typing of avian influenza viruses from oropharyngeal samples of ducks. Avian Diseases 55 : 439-42.

4. Ellis TM, Barry BR, Bissett LA, Dyrting KC, Luk GS, Tsim ST, Sturm-Ramirez K, Webster RG, Guan Y and Malik Peiris JS (2004). Investigation of outbreaks of highly pathogenic H5N1 avian influenza in waterfowl and wild birds in Hong Kong in late 2002. Avian Pathology 33 : 492-505.

5. FAO (2010). Duck Farming Systems and Avian Influenza in the Mekong Delta of Viet Nam, by Bui Xuan.

6. Fouchier RA, Munster V, Wallensten A, Bestebroer TM, Herfst S, Smith D, Rimmelzwaan GF, Olsen B and Osterhaus AD (2005). Characterization of a novel influenza A virus hemagglutinin serotype (H16) obtained from black-headed gulls. Journal of Virology 79 : 28142822.

7. Gaidet NA, Caron J, Cappelle GS, Cumming G, Balança S, Hammoumi G, Cattoli C, Abolnik R, Servan de Almeida P, Gil SR, Fereidouni V, Grosbois A, Tran J, Mundava B, Fofana AB, Ould El, Mamy M, Ndlovu JY, Mondain-Monval P, Triplet11 W, Hagemeijer WB, Karesh SH, Newman and Dodman T (2012). Understanding the ecological drivers of avian influenza virus infection in wildfowl: a continental-scale study across Africa. Proceedings of the Royal Society B: Biological Sciences 279 : 1131-1141.

8. Hulse-Post DJ, Sturm-Ramirez KM, Humberd J, Seiler P, Govorkova EA, Krauss S, Scholtissek C, Puthavathana P, Buranathai C, Nguyen TD, Long HT, Naipospos TS, Chen H, Ellis TM, Guan Y, Peiris JS and Webster RG (2005). Role of domestic ducks in the propagation and biological evolution of highly pathogenic H5N1 influenza viruses in Asia. Proceedings of the National Academy of Sciences of the United States of America 102 : 10682-10687.

9. Krauss S, Walker D, Pryor SP, Niles L, Chenghong L, Hinshaw VS and Webster RG (2004). Influenza A viruses of migrating wild aquatic birds in North America. Vector Borne Zoonotic Diseases 4 : 177-189.

10. Majumder R, Chowdhury EH, Parvin R, Begum JA, Giasuddin M and Islam MR (2011). Development of multiplex reverse transcription polymerase chain reaction (RT-PCR) for simultaneous detection of matrix,haemagglutinin and neuraminidase genes of $\mathrm{H} 5 \mathrm{~N} 1$ avian influenza virus. The Bangladesh Veterinarian $28: 55-59$.

11. Munster VJC, Bass P, Lexmond TM, Bestebroer J, Guldemeester WEP, Beyer E, Wit De, Schutten M, Rimmelzwaan GF, Osterhaus ADME and Fouchier ADME (2009). Practical considerations for highthroughput influenza A virus surveillance studies of wild birds by use of molecular diagnostic tests. Journal of Clinical Microbiology 47: 666-673.

12. Nooruzzaman M, Hoque E, Chowdhury EH and Islam MR (2012). Highly pathogenic avian influenza virus of clade 2.3.2.1 in quails and ducks in Bangladesh. Proceeding at BSVER ASCon XVIII, BAU, Mymensingh, February 2012, pp. 18-19.

13. Office International des Epizooties (OIE) (2008). Manual of Diagnostic Tests Vaccines for Terrestrial Animals. Part 2, Section 2.3, Chapter 2.3.4, $6^{\text {th }}$ ed. Avian influenza, Paris, France, pp. 456-481.

14. Olsen B, Munster VJ, Wallensten A, Waldenstrom J, Osterhaus AD and Fouchier RA (2006). Global patterns of influenza a virus in wild birds. Science 312 : 384-388.

15. Rahman MS, Rabbani MG, Uddin MJ, Chakrabartty A and Moon Her (2012). Prevalence of Avian Influenza and Newcastle Disease Viruses Using Rapid Antigen Detection Kit in Poultry in Some Areas of Bangladesh. Archives of Clinical Microbiology 3 (1) doi: 10.38.23/248.

16. Sturm-Ramirez KM, Ellis T, Bousfield B, Bissett L, Dyrting K, Rehg JE, Poon L, Guan Y, Peiris M and Webster RG (2004). Reemerging H5N1 Influenza Viruses in Hong Kong in 2002 are Highly Pathogenic to Ducks. Journal of Virology 78 : 4892-4901.

17. Wallensten A, Munster VJ, Latorre-Margalef N, Brytting M, Elmberg J, Fouchier RA, Fransson T, Haemig PD, Karlsson M, Lundkvist A, Osterhaus AD, Stervander M, Waldenström J and Björn O (2007). Surveillance of influenza A virus in migratory waterfowl in northern Europe. Emerging Infectious Disease 13 : 404-11.

18. Webster RG, Bean WJ, Gorman OT, Chambers TM and Kawaoka Y (1992). Evolution and Ecology of Influenza A Viruses. Microbiological Review 56 : 152-179. 